\title{
IMTATION OF LIFE
}



FANNIE HURST

Edited and with an Introduction by

Daniel Itzkovitz

Duke University Press

Durham and London

2004 
(C) 2004 Duke University Press

All rights reserved

Printed in the United States of America

on acid-free paper $\infty$

Library of Congress Cataloging-

in-Publication Data appear on the last

printed page of this book.

Imitation of Life (C) I 933 by Fannie Hurst Danielson. Copyright renewed (c) I960

by Fannie Hurst Danielson. Reprinted by permission of Brandeis University and Washington University, co-executors of The Fannie Hurst Danielson Estate. Misspellings and typographical errors have been silently corrected in this edition. 